\title{
Bilateral occipital strokes from an atherosclerotic trigeminal artery
}

Figure 1 Diffusion-weighted MRI showing bilateral occipital infarcts

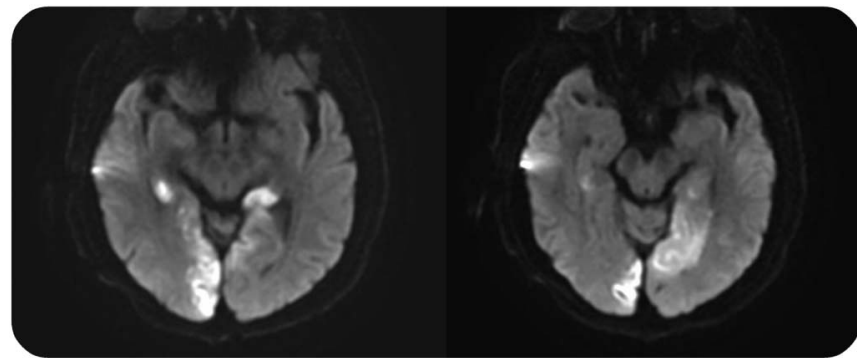

Diffusion abnormalities in the lingual and parahippocampal gyri.

A 58-year-old man with coronary disease presented with headache, confusion, and vision loss. On examination, he had retrograde and anterograde amnesia, superior homonymous quadrantanopias, and could not identify colors. MRI showed bilateral occipital infarcts involving the parahippocampal and lingual gyri (figure 1). CT angiography revealed a hypoplastic vertebrobasilar circulation, with a persistent right trigeminal artery supplying the rostral basilar artery (figure 2). Persistent fetal arteries may increase risk of atherogenesis due to increased turbulence. ${ }^{1}$ A rare cortical syndrome, new-onset achromatopsia with amnesia should provoke concern for top of the basilar syndrome. ${ }^{2}$ In this case, fetal artery intracranial atherosclerosis resulted in a "top of the trigeminal" syndrome.

Eliza C. Miller, MD, Joshua Z. Willey, MD, MSc

From the Department of Neurology, College of Physicians and Surgeons, Columbia University, New York, NY.

Author contributions: Dr. Miller: drafting manuscript, designing figures. Dr. Willey: critically reviewing and revising manuscript for intellectual content.

Study funding: No targeted funding reported.

Disclosure: E. Miller reports no disclosures relevant to the manuscript. J. Willey received funds from the NIH (NINDS K23 073104) and is a consultant for Heartware Incorporated. Go to Neurology.org for full disclosures.

Correspondence to Dr.Miller:ecm2137@cumc.columbia.edu

1. Menshawi K, Mohr JP, Gutierrez J. A functional perspective on the embryology and anatomy of the cerebral blood supply. J Stroke 2015;17:144-158.

2. Kraft A, Grimsen C, Kehrer S, et al. Neurological and neuropsychological characteristics of occipital, occipito-temporal and occipito-parietal infarction. Cortex 2014;56:38-50. 


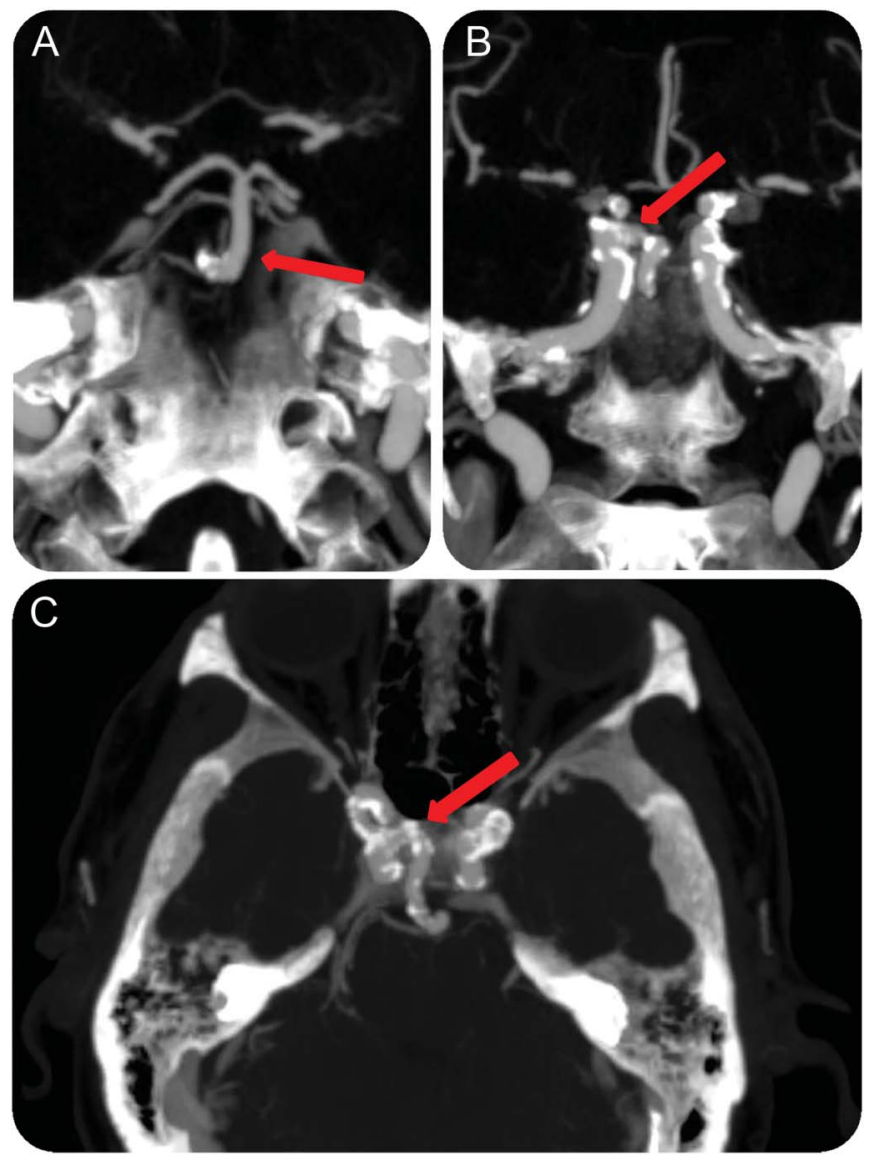

Coronal sections through the rostral basilar artery demonstrate supply by a persistent right trigeminal artery (A, B, arrows). There is severe intracranial atherosclerosis, with dilated and tortuous carotid arteries. Axial section (C) shows severe stenosis at the origin of the trigemino-basilar system (arrow).

\section{WriteClick ${ }^{\circledR}$ rapid online correspondence}

Have a comment on a recent Neurology ${ }^{\circledR}$ article you would like to share? Now it is easier and more convenient. Neurology.org has launched WriteClick on the home page and sidebars of each article to encourage remarks and debate among users.

WriteClick is restricted to comments about studies published in Neurology within the last eight weeks.

Learn more at Neurology.org/letters 


\section{Neurology}

\section{Bilateral occipital strokes from an atherosclerotic trigeminal artery Eliza C. Miller and Joshua Z. Willey \\ Neurology 2016;86;489-490 \\ DOI 10.1212/WNL.0000000000002342}

\section{This information is current as of February 1, 2016}

\section{Updated Information \&} Services

References

Subspecialty Collections

Permissions \& Licensing

Reprints including high resolution figures, can be found at: http://n.neurology.org/content/86/5/489.full

This article cites 2 articles, 0 of which you can access for free at: http://n.neurology.org/content/86/5/489.full\#ref-list-1

This article, along with others on similar topics, appears in the following collection(s):

All Cerebrovascular disease/Stroke

http://n.neurology.org/cgi/collection/all_cerebrovascular_disease_strok

All Imaging

http://n.neurology.org/cgi/collection/all_imaging

Information about reproducing this article in parts (figures,tables) or in its entirety can be found online at:

http://www.neurology.org/about/about_the_journal\#permissions

Information about ordering reprints can be found online:

http://n.neurology.org/subscribers/advertise

Neurology ${ }^{\circledR}$ is the official journal of the American Academy of Neurology. Published continuously since 1951, it is now a weekly with 48 issues per year. Copyright (O 2016 American Academy of Neurology. All rights reserved. Print ISSN: 0028-3878. Online ISSN: 1526-632X.

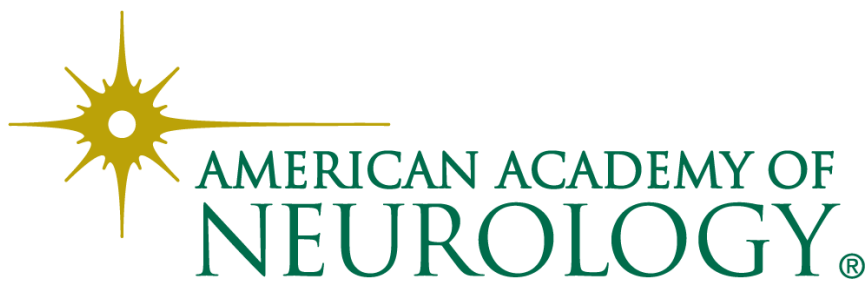

